\title{
COVID-19 and Gender: A Necessary Connection in Diplomatic Studies
}

\author{
Ann E. Towns, ${ }^{a}$ Katarzyna Jezierska, ${ }^{b}$ Anne-Kathrin Kreft ${ }^{a}$ \\ and Birgitta Niklasson ${ }^{a}$ \\ aDepartment of Political Science, University of Gothenburg, \\ Gothenburg, Sweden \\ bDivision of Law, Economics, Statistics and Politics, University West, \\ Trollhättan, Sweden \\ ann.towns@gu.se; katarzyna.jezierska@hv.se; anne-kathrin.kreft@gu.se; \\ birgitta.niklasson@pol.gu.se
}

Received: 15June 2020; revised: 13 July 2020; accepted: 13 September 2020

\section{Summary}

The COVID-19 crisis has fundamentally gendered effects, on intimate partner violence, the division of care labour, healthcare and more. This, and other coviD-19-related changes, may have important consequences for the gendered practice of diplomacy. This essay therefore discusses COVID-19 to highlight the need to pay better attention to gender in the study of diplomacy. For instance, what are the gender dimensions of diplomacy moving online? What are the gendered implications of the increased pressures on consular diplomacy? Turning to longer-term issues, how do gender justice organisations that respond to COVID-19 target diplomats and embassies? How, in turn, do diplomats respond to such advocacy and the underlying problems they address, and does the recent increase in women diplomats make any difference? Gender and diplomacy are intimately interwoven, this essay contends, and understanding the implications of COVID-19 on diplomacy necessitates examining this connection.

\section{Keywords}

diplomacy - diplomatic practice - gender - COVID-19 - civil society - feminist foreign policy - digital diplomacy 
The COVID-19 pandemic — potentially the most challenging global crisis since World War II - is developing in a world of inequalities. Reports from around the world indicate inequalities shape who is affected and how, with differential impacts that vary by age, class, race, ethnicity, ability, sexuality and so on. In this essay, we put in focus the fundamentally gendered effects of the crisis to discuss some of the implications for diplomacy.

There are, indeed, countless accounts of the ways in which gender matters in the corona calamity. With lockdowns and confinements to the home, intimate partner violence has spiked globally, by UN estimates around by 20-30 per cent. ${ }^{1}$ The UN Population Fund (UNFPA) estimates that for every three months of lockdown, there will be an excess 15 million cases of domestic violence worldwide. ${ }^{2}$ The UNPFA also projects that, due to major disruptions to services, around 47 million women in 114 low- and middle-income countries will be unable to use modern contraceptives if current lockdowns and service disruptions continue for six months. ${ }^{3}$ Unintended and unwanted pregnancies will thus be on the rise. Furthermore, since many labour markets are gender stratified, men and women often face different challenges and types of risk exposure at work. For instance, in the United States, non-white women are more likely to be doing 'essential jobs' - jobs that are not subject to corona-related restrictions - than any other demographic group. ${ }^{4}$ Globally, men make up only 33 per cent of the health workforce. ${ }^{5}$ For those ordered to work from home, the uneven division of care labour generally places a lighter burden on men, as women often take primary responsibility for childcare, home schooling and domestic chores. Not surprisingly, the introduction of gender-based lockdowns in parts of Latin America, with men and women allowed out on alternate days, has led to overcrowding in food stores on women's days out. ${ }^{6}$ This binary policy has likewise unleashed additional violence against trans people, a reminder that gender is always implicated in other relations of inequality and that gender analyses should include intersectional perspectives. Indeed, it is crucial to take into account the 'multiplier effect of burdens'7 and the many

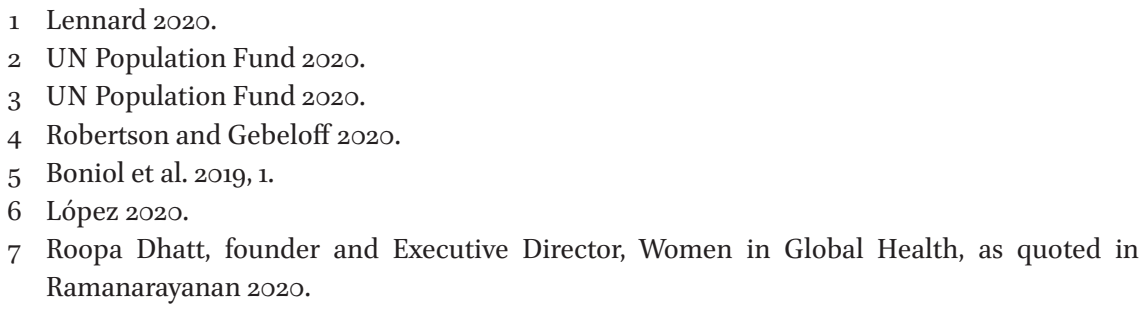


ways that, for example, race, class, sexuality and gender may exacerbate and mitigate the effects of the corona crisis for differently situated groups.

The gender dynamics of the corona crisis also have implications for diplomacy, this essay contends, highlighting the need to pay better attention to gender in the study of diplomacy during the crisis and beyond. On the one hand, there are gender inequalities in diplomatic work as such, and these may transform along with the adaptations of diplomatic interactions to the lockdowns and travel restrictions. For instance, as suggested below, the move to online interactions and consular diplomacy are likely to have important gender implications that merit further study. On the other hand, the corona-related exacerbation of gender inequalities outside of diplomacy may also have repercussions for diplomatic work. For instance, civil society actors are already mobilising in response to effects of the crisis. Will women's advocacy groups and other forms of gender justice organisations that address increasing inequalities step up their networking with like-minded diplomats and embassies? How, in turn, do diplomats and other foreign policy actors — such as those responsible for feminist foreign policies - respond to such advocacy and the underlying problems they address? Does the recent diversification of diplomatic services, which includes an increase in women, make any difference in how diplomacy responds? Gender and diplomacy are intimately interwoven, this essay argues, and understanding the implications of CoviD-19 on diplomacy necessitates examining this connection.

\section{2 \\ The Shorter Term: Gender in Diplomacy's Turn to Online and Consular Activities}

A global pandemic is a major challenge for diplomacy. As countries enforce measures to halt infection rates and protect their citizens, many responses have had a direct impact on the practice of diplomacy. The closing of borders, the cancellation of visits and international fora and the various lockdowns and physical distancing measures have forced diplomats to focus on corona-related matters and to put a halt to many standard forms of diplomatic interactions. ${ }^{8}$ Just as diplomatic practice under more normal circumstances is gendered, this essay argues, these changes in how diplomacy is done are likely to have deeply gendered implications. To illustrate how, it discusses diplomacy's move online and the increased focus on consular activities to keep citizens safe.

8 Brodsky 2020. 


\subsection{Gender and Online Activities}

As many have already noted before us, due to the policy responses to COVID-19, diplomacy has been forced online. ${ }^{9}$ Prior to the corona outbreak, compared to other actors such as the military, diplomacy had been slow on the technological uptake. ${ }^{10}$ The use of digital diplomacy has generally served as an additional rather than a primary arena for diplomats. ${ }^{11}$ Diplomatic missions have relied heavily on face-to-face interactions, with much traveling and frequent meetings, including evening commitments that may contain dinners and receptions. Feminist scholarship has shown that, generally, diplomatic protocol and diplomatic representation entail more labour for women, who have to spend more time and effort to meet diplomatic dress and appearance expectations ${ }^{12}$ and who may spend more time directly involved in the planning of luncheons, teas, dinners and receptions. Work outside regular office hours is also harder to combine with having a family, particularly for female diplomats who are parents as they often have more parental responsibilities than their male colleagues. ${ }^{13}$ Analyses of other professions have already shown inequalities between men and women to grow with the move to online work from home.

When video conferences take the place of meetings in real life (IRL), diplomatic protocol and dress code issues likely become more flexible. ${ }^{14}$ As coronarelated restrictions temporarily relieve diplomats of some of standard social obligations, the gender dynamics and inequalities mentioned above may be neutralised; for instance, by reducing the time required for physically representability. What is more, physical groping is difficult online. On the other hand, the move online may also deprive women of the opportunity to stand out in a crowd of male diplomats, a tactic that prior scholarship has identified. ${ }^{15}$ This strategy may be harder to apply in an online situation where all attendants appear as talking heads.

When interpersonal interactions IRL are no longer an option, do diplomats rely more heavily on pre-corona contacts? Do they find new ways of establishing relations online? Recent research indicates that diplomats may find it more difficult to interact with people of the opposite sex outside formal settings, particularly when posted in less gender equal countries. ${ }^{16}$ These are

\footnotetext{
$9 \quad$ For example, Chowdhury Fink 2020.

10 Copeland 2013, 453.

11 Cull 2013.

12 Towns 2019.

13 Niklasson 2020, 36.

14 Brodsky 2020.

15 Niklasson 2020, 26.

16 Niklasson 2020, 37.
} 
also countries where men tend to control the large majority of public power positions. This begs the question of how online networking affects female diplomats' access to men in these positions. Feminist research also warns that the digital sphere - especially when open to public interactions - is marked by gendered online abuse. ${ }^{17}$ Has online harassment increased with the increased reliance on social media? There is surely much more to learn about the gender dynamics of digital diplomacy. ${ }^{18}$

\subsection{Gender and Consular Activities}

A second immediate implication of COVID-19 is that consular diplomacy has become more important. The swift shutdown of borders has led to a surge in demand for consular assistance. As a result, the work of most bilateral diplomatic missions is now largely focused on monitoring information on the spread of the virus, assessing the needs of nationals abroad, and assisting citizens in need of help.

In terms of scholarship, consular practice is the less studied dimension of diplomacy, ${ }^{19}$ often treated as less prestigious. ${ }^{20}$ Given its lower status, it is perhaps not surprising that consular work is associated with the 'feminine' duty of care for nationals abroad ${ }^{21}$ and that this work, compared to other forms of diplomacy, is more often performed by women. ${ }^{22}$ Prior emergencies made ministries of foreign affairs aware that consular affairs may be of national interest, a point which the more enduring CoviD-19 crisis is likely to drive home.

What are the gendered implications of the increased pressures on consular diplomacy? Will coviD-19 help raise the status of consular work? What would be the gendered consequences for diplomatic careers? A revaluing of consular diplomacy might have broader implications. As Fiona Robinson has argued, a critical feminist ethics of care can have a potentially radical and transformative effect on international relations, which may entail a questioning of different types of hierarchies. ${ }^{23}$ Can a reappraisal of consular diplomacy in the wake of COVID-19 result in an increased focus on moral responsiveness in international relations derived from an ethics of care? How might this be gendered?

\footnotetext{
17 For example, Levey 2018; Ging and Siapera 2018.

18 Cf. Jezierska 2019.

19 Melissen and Okano-Heijmans 2018.

$20 \quad$ Leira and Neumann 2018, 170.

21 Graeger and Leira 2019.

22 Niklasson and Robertson 2018, 76.

23 Robinson 2019.
} 

to Gender Issues?

In response to the corona crisis, civil society actors across the world have engaged in a range of activities to draw attention to the ways in which communities are differentially affected. Women's rights and other gender justice organisations are no exception. For instance, in Peru, the gender-based lockdown generated fierce resistance among women, who claimed that the measure was counterproductive as it increased the exposure of women to COVID-19 and added to their already disproportionate share of domestic labour. ${ }^{24}$ The measure was overturned a week after it was put in place. Likewise, lesbian, gay, bisexual, transgender, and queer (or questioning) and others activists have protested the increased harassment of non-binary and transgender people by the police during gender-based lockdowns. ${ }^{25}$ The spike in domestic violence, what the UN calls a 'shadow pandemic', has led to calls for quick countermeasures and increased funding (e.g., for shelters) around the world. ${ }^{26}$ Activists, labour leaders and community organisations are using the corona crisis to mobilise support for fair recognition of and remuneration for women's care labour — paid and unpaid. ${ }^{27}$

Civil society organisations have a history of directing advocacy at diplomats. Civil society activism can be antagonistic such as the anti-apartheid picket at the South African Embassy in London in the late 1980s. ${ }^{28}$ But it is also often collaborative, seeking to persuade, engage and recruit bilateral as well as multilateral diplomats to support their causes. ${ }^{29}$ Particularly illustrative of the ever-closer partnerships between diplomats and civil society actors is the formalised channels at the United Nations, where some 4,000 nongovernmental organisations enjoy consultative status with the UN Economic and Social Council which grants them access to UN conferences and different UN bodies. ${ }^{30}$ Largely overlooked in diplomacy scholarship are the relations between civil society actors and the personnel of resident embassies, however. ${ }^{31}$ The CoviD-19 crisis thus amplifies an already existing need among diplomacy scholars to examine the relations between civil society actors and diplomats,

\footnotetext{
24 López 2020.

25 López 2020; Griffin and Rivera Antara 2020.

$26 \quad$ Wikipedia 2020.

27 Rai and True 2020.

28 Browne and Yaffe 2013.

29 For example, Towns 2010.

30 Willetts 2000.

31 GenDip.
} 
and to what extent these relations may change as the gender composition of diplomats changes.

Yet civil society activists' potential to engage diplomats is under strain, due to a rise in right-wing populism, nationalism and autocratisation, accompanied by crackdown on civil society organising in different parts of the world. ${ }^{32}$ Further amplifying these processes, some states are instrumentalising coronavirus containment measures to curtail freedom of speech, fundamental rights or institutional checks and balances. A new data collection effort attests that as many as 48 states are at a high risk of authoritarian backsliding as a result of the Covid-19 pandemic. ${ }^{33}$ Women are differentially affected by such developments owing to an additional layer of anti-gender mobilisation around 'traditional family values,' which inter alia calls into doubt gains made towards gender equality and women's full participation in society and often seeks to undermine women's civil society activism. ${ }^{34}$ This 'anti-gender backlash' is further magnified by the corona crisis and the developments discussed in the introduction.

Civil society actors are not sitting idly by, however. They are adapting their operations to a new reality, they are moving their activism online, they are also mobilising specifically around the (gendered) challenges caused or exacerbated by the Covid-19 pandemic such as under-equipped hospitals, economic insecurity and the spike in domestic violence. ${ }^{35}$ Many frame the gendered fallout from CoviD-19 in 'security' terms, as a matter of 'human security'36 and even 'health security' ${ }^{37}$ How would framing healthcare as 'security' — an often masculinised concept central to diplomacy - transform collaborations between diplomats and civil society actors? More generally, how do civil society actors reach out to and target diplomats? Do they use embassies as platforms and, if so, in what ways?

\section{Conclusions: Will Rising Numbers of Women Diplomats Save the Day?}

This brief essay has shown that CoviD-19 has gendered dimensions with implications for diplomacy, calling on diplomacy scholars to pay better attention

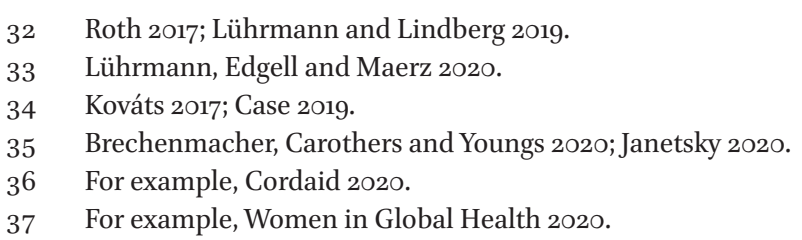


to the intimate connections between gender and diplomacy. Diplomacy is furthermore a conduit for gender-oriented foreign policy, including the expressly feminist foreign policies adopted by a growing number of states. Asking questions about how diplomacy and diplomats respond to the gender inequalities exacerbated by COVID-19 thus partially entails asking how diplomats interpret and implement foreign policy. This, in turn, may involve asking about the ways in which various gender dimensions may shape that implementation. One such gender dimension concerns the historical dominance of diplomatic positions by men and the recent increase of women in diplomacy. ${ }^{38}$ Indeed, as members of the GenDip Program on Gender and Diplomacy, the authors of this essay are regularly asked about the potential effects on various outcomes that may result from the changing gender composition of the diplomatic community - that is, do women make a difference to diplomacy? While none of the authors centre this question in their diplomacy research, in a gender stratified world, this is a question that demands more attention. For instance, Sylvia Bashevkin has shown that while not all female foreign policy leaders push a gender equality agenda, they are more likely to do so than their male counterparts. ${ }^{39}$ There is plenty of research on legislatures and executives which has shown that men in public office generally put less stress on reproductive health, childcare and elderly care, and that they are less attuned to the interests of politically marginalised groups such as women, ethnic minorities and children than are women. With quickly rising numbers of women in diplomacy, such claims are worth interrogating in diplomacy scholarship as well, while paying careful attention to intersectional perspectives and the multiple hierarchies of which gender is a part. Understanding the implications for and role of diplomacy in the exacerbation of inequalities that seem to be developing with CoviD-19 should be a crucial part of the diplomacy studies agenda.

\section{Bibliography}

Bashevkin, Sylvia. Women as Foreign Policy Leaders: National Security and Gender Politics in Superpower America (Oxford: Oxford University Press, 2020).

Boniol, Mathieu, Michelle McIsaac, Lihui Xu, Tana Wuliji, Khassoum Diallo and Jim Campbell. 'Gender Equity in the Health Workforce: Analysis of 104 Countries'. Working Paper No. 1 (Geneva: World Health Organization, 2019). WHO/HIS/HWF/ Gender/WP1/2019.1.

$38 \quad$ Towns and Niklasson 2017.

39 Bashevkin 2020, 222. 
Brechenmacher, Saskia, Thomas Carothers and Richard Youngs. 'Civil Society and the Coronavirus: Dynamism despite Disruption'. Carnegie Endowment for International Peace, 21 April 2020. https://carnegieendowment.org/2020/04/21/civil -society-and-coronavirus-dynamism-despite-disruption-pub-81592.

Brodsky, Michael. 'Diplomacy after the Coronavirus'. The Jerusalem Post, 4 April 2020.

Brown, Gavin and Helen Yaffe. 'Non-Stop against Apartheid: Practicing Solidarity outside the South African Embassy'. Social Movement Studies 12 (2) (2013), 227-234.

Case, Mary Anne. 'Trans Formations in the Vatican's War on “Gender Ideology”'. Signs: Journal of Women in Culture and Society 44 (3) (2019), 639-664.

Chowdhury Fink, Naureen. 'Diplomacy at the UN in the Time of Coronavirus'. IPI Global Observatory, 6 April 2020.

Copeland, Daryl. 'Digital Technology'. In The Oxford Handbook of Modern Diplomacy, eds. Andrew Cooper, Jorge Heine and Ramesh Thakur (Oxford: Oxford University Press, 2013), 453-472.

Cordaid. 'Human Security at Stake: The Gendered Impact of Covid-19 in War-Torn Libya'. Policy Brief, May 2020. https://reliefweb.int/sites/reliefweb.int/files/resources/ 20200508-The-Engendered-Impact-of-COVID-19-in-Libya-PC-8504YV1.pdf.

Cull, Nicholas J. 'The Long Road to Public Diplomacy 2.0: The Internet in US Public Diplomacy'. International Studies Review 15 (1) (2013), 123-139.

GenDip. Research project on civil society and feminist foreign policy. https://www .gu.se/en/gender-and-diplomacy.

Ging, Debbie and Eugenia Siapera. 'Special Issue on Online Misogyny'. Feminist Media Studies 18 (4) (2018), 515-524.

Graeger, Nina and Halvard Leira, eds. The Duty of Care in International Relations: Protecting Citizens Beyond the Border (London: Routledge, 2019).

Griffin, Jo and Daniela Rivera Antara. "Separation by Sex": Gendered Lockdown Fueling Hate Crime on Streets of Bogotá'. The Guardian, 8 May 2020.

Janetsky, Megan. 'Violence against Women up amid Latin America COVID-19 Lockdowns'. Al Jazeera, 20 April 2020.

Jezierska, Katarzyna. 'Incredibly Loud and Extremely Silent: Feminist Foreign Policy on Twitter'. Paper presented at the GenDip Workshop, University of Gothenburg, 28 June 2019.

Kováts, Eszter. 'The Emergence of Powerful Anti-Gender Movements in Europe and the Crisis of Liberal Democracy'. In Gender and Far Right Politics in Europe, eds. Michaela Köttig, Renate Bitzan and Andrea Petö (Cham: Springer International, 2017), 175-189.

Leira, Halvard and Iver B. Neumann. 'Consular Diplomacy'. In Diplomacy in a Globalizing World: Theories and Practices, eds. Pauline Kerr and Geoffrey Wiseman (New York: Oxford University Press, 2018), 170-184. 
Lennard, Natasha. 'Domestic Violence Is on the Rise with Coronavirus Lockdown: The Responses Are Missing the Point'. The Intercept, 13 April 2020.

Levey, Tania G. Sexual Harassment Online: Shaming and Silencing Women in the Digital Age (Boulder: Lynne Rienner, 2018).

López, Canela. 'Peru Reverses Its Controversial Gender-Based Lock-Down, Quarantining Men and Women on Different Days, after Intense Backlash'. Business Insider, 13 April 2020.

Lührmann, Anna, Amanda B. Edgell and Seraphine F. Maerz. 'Pandemic Backsliding: Does Covid-19 Put Democracy at Risk?' V-Dem Policy Brief No. 23, 2020. https:// www.v-dem.net/media/filer_public/52/eb/52eb913a-b1ad-4e55-9b4b-371off7odıbf/ pb_23.pdf.

Lührmann, Anna and Staffan I. Lindberg. 'A Third Wave of Autocratization Is Here: What Is New about It?' Democratization 26 (7) (2019), 1095-1113.

Melissen, Jan and Maaike Okano-Heijmans. 'Introduction: Diplomacy and the Duty of Care'. The Hague Journal of Diplomacy 13 (2) (2018), 137-145.

Niklasson, Birgitta. 'The Gendered Networking of Diplomats'. The Hague Journal of Diplomacy 15 (1-2) (2020), 13-42.

Niklasson, Birgitta and Felicia Robertson. 'The Swedish MFA — Ready to Live up to Expectations'? In Gendering Diplomacy and International Negotiation, eds. Karin Aggestam and Ann Towns (Basingstoke: Palgrave Macmillan, 2018), 65-86.

Rai, Shirin and Jacqui True. 'A Regenerative State or Business as Usual?' Think Development (blog), 15 May 2020. https://blogs.warwick.ac.uk/pogo1/entry/a_re generative_state/?fbclid=IwARoLE5E8JF-S7NiRsXaOVY8jjnXtiMaZrThwWO 4TolAmNiwctBfbqF7IS6k.

Ramanarayanan, Deekshita. 'COVID-19 Shines Spotlight on Race and Gender Inequities in Health Care'. NewSecurityBeat (blog), 12 May 2020. https://www.newsecuritybeat .org/2020/05/covid-19-shines-spotlight-race-gender-inequities-healthcare/.

Robertson, Campbell and Robert Gebeloff. 'How Millions of Women Became the Most Essential Workers in America'. The New York Times, 18 April 2020.

Robinson, Fiona. 'Feminist Foreign Policy as Ethical Foreign Policy? A Care Ethics Perspective'. Journal of International Political Theory (2019). DOI 10.1177/ 1755088219828768.

Roth, Kenneth. 'The Dangerous Rise of Populism: Global Attacks on Human Rights Values'.Journal of International Affairs (2017), 79-84, special 7oth anniversary issue. Stephenson, Elise and Susan Harris. 'Covid-19 Responses: Why Feminist Leadership Matters in a Crisis'. The Interpreter, 31 March 2020.

Towns, Ann. 'The Inter-American Commission of Women and Women's Suffrage, 19201945'. Journal of Latin American Studies 42 (2010), 779-807. 
Towns, Ann. 'Body Work of Ambassadors: Performance Labor, Gender and Sexuality in

Diplomacy'. Paper presented at the GenDip Workshop, University of Gothenburg, 28 June 2019.

Towns, Ann and Birgitta Niklasson. 'Gender, International Status, and Ambassador Appointments'. Foreign Policy Analysis 13 (2017), 521-540.

UN Population Fund. 'Impact of the Covid-19 Pandemic on Family Planning and Ending Gender-Based Violence, Female Genital Mutilation and Child Marriage'. 27 April 2020. https://www.unfpa.org/resources/impact-covid-19-pandemic-family -planning-and-ending-gender-based-violence-female-genital.

Wikipedia. 'Impact of the Covid-19 Pandemic on Domestic Violence'. 2020. https:// en.wikipedia.org/wiki/Impact_of_the_COVID-19_pandemic_on_domestic_vio lence.

Willetts, Peter. 'From Consultative Arrangements to Partnership: The Changing Status of NGOs in Diplomacy at the UN'. Global Governance 6 (2) (2000), 191-212.

Women in Global Health. 'Global Health Security Depends on Women'. 2020. https:// www.womeningh.org/5-asks.

\section{Ann Towns}

is Professor of Political Science at the University of Gothenburg and a Wallenberg Academy Fellow. She leads GenDip, a research program on gender in diplomacy (https://gendip.gu.se), awarded a Bertha Lutz Prize from the International Studies Association in 2018. Her own project within GenDip centers on intersections between gender and international hierarchies in bilateral diplomacy. Towns is the author of Women and States: Norms and Hierarchies in International Society (Cambridge University Press 2010) and of articles in International Organization, European Journal of International Relations, Review of International Studies, Millennium, Party Politics, Foreign Policy Analysis and many other venues.

\section{Katarzyna Jezierska}

is Associate Professor of Political Science, University West, Sweden, and a Researcher at the GenDip program. She works in the broader field of political sociology with an empirical focus on Central Europe. Her research interests span civil society, policy advice, democratic theory and diplomacy, and she co-runs a project on the gendered relations between diplomats and civil society within feminist foreign policy. She has published on these topics in journals such as Governance, VOLUNTAS: International Journal of Voluntary and Nonprofit Organizations, Europe-Asia Studies, East European Politics and Societies, Journal of Public Deliberation, Politics and Governance, Place 
Branding and Public Diplomacy, as well as edited books with Routledge and Palgrave Macmillan.

\section{Anne-Kathrin Kreft}

is a Postdoctoral Researcher in Political Science at the University of Gothenburg, a Visiting Researcher at the Centre for Gender Research at the University of Oslo and a member of the GenDip Network. She completed her $\mathrm{PhD}$ on conflict-related sexual violence and women's political agency in 2019 and continues to work on gender-based violence. She is the recipient of the 2020 Christiane-Rajewsky-Award for emerging conflict scholars and of the 2019 James Caporaso best paper award from Comparative Political Studies. She has also published in the Journal of Peace Research, Journal of Conflict Resolution, International Affairs and International Peacekeeping.

\section{Birgitta Niklasson}

is Associate Professor of Political Science, University of Gothenburg, and a Researcher at the GenDip program. Her work focuses on public administration and diplomacy, and more specifically on issues related to gender and careers in political and administrative contexts. Her current research focuses on gender in the Swedish Ministry for Foreign Affairs and how gender shapes diplomatic work. Her work has appeared in journals such as Public Administration, West European Politics, Foreign Policy Analysis and The Hague Journal of Diplomacy. 